Article History:

Submitted:

6 November 2020

Reviewed:

4 January 2021

Edited:

14 January 2021

28 January 2021

Accepted:

28 January 2021

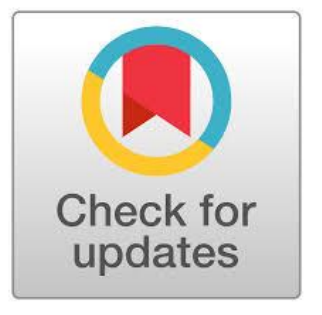

\section{Word Recognition and Reading Skills to Improve Reading Comprehension}

\author{
Mayra Yadira Chamba ${ }^{1}$, Maria Rossana Ramirez-Avila ${ }^{2}$ \\ ${ }^{1,2}$ Universidad Casa Grande, Ecuador \\ 1mavra.chamba@casagrande.edu.ec \\ 2mramirez@casagrande.edu.ec
}

DOI: https://doi.org/10.18196/ftl.v6i1.10174

\begin{abstract}
This research aimed at showing the influence of word recognition, and using skimming and scanning skills to improve reading comprehension. Participants were a group of 15 students whose ages ranged from 14 to 16 . They had problems in reading comprehension and vocabulary. This action research was conducted at a private language institute. The instruments to collect data were pre- and post-surveys, pre- post-tests, learning logs, skimming and scanning forms, and an interview. They provided quantitative and qualitative information. Results showed that there was a statistically significant improvement in parts of speech knowledge from the pre- to the posttest. The result was an average improvement of $28.2 \%$ in student performance. Cohen's $d$ was calculated with a result of 1.09 which means there is impact in learning. There was also a steady improvement in skimming and scanning which was exemplified by the ability to correctly complete a form after reading texts. Lastly, students' perspectives were positive to this innovation. Therefore, it is advisable to apply the same innovation with other learners in order to compare results of improvement of reading comprehension and overall proficiency.
\end{abstract}

Keywords: skimming; scanning; word recognition; reading comprehension; language school 


\section{Introduction}

Reading and language proficiency are connected. Studies have found positive correlations between students who read substantially and high academic performance. This helps them expand their vocabulary and consequently gain knowledge in other academic content areas, in the target language (L2) and in their mother tongue (Short et al., 2018). In this regard, the Programme for International Students Assessment (PISA) performed an assessment to measure the level of reading proficiency among member countries of the Organization for Economic Cooperation and Development (OECD, 2016). Results indicated that only 12 out of 42 countries have made progress since 2000. The others have either declined results or have remained at the same proficiency level. These results force educators to reconsider the different aspects that influence literacy acquisition in students' L1 in addition to that of a foreign language (OECD, 2016).

Ecuador has specific proficiency objectives related to English language education which include the skill of reading. One of the objectives is to apply correct reading comprehension techniques to understand any type of texts (Ministerio de Educación, 2012). Despite the efforts to meet them, Ecuador English levels are low. The EF English Proficiency Index (EPI) reports that the English level in Latin America (50.33\%) is lower than in Europe (56.64\%). This represents a low proficiency and a moderate proficiency respectively (Education First, 2020), and Ecuador is in the 93rd place with a very low proficiency.

The National Institute of Statistics and Census in Ecuador (INEC) reported that 26.5\% of people do not possess the habit of reading in L1. Some of the reasons are a lack of interest in reading, lack of time, and difficulties maintaining concentration. Similarly, in this report people stated that they like to read at home more than at school; and, prefer mainly to read newspapers (Instituto Nacional de Estadisticas y Censos, 2012).

At the level of primary and secondary school and language institutes research related to the impact of incrementing vocabulary to improve reading comprehension is scarce in the local context. There is research that studied the connection between vocabulary and reading comprehension in international higher education institutions. Laufer and Ravenhorst-Kalovski (2010) collected data from 745 Israeli students who were enrolled in an English for Academic Purposes class. The authors concluded that vocabulary size contributes to a better reading comprehension. Another study established that knowing the meaning of words was an effective 
Journal of Foreign Language Teaching and Learning

Volume 6, No. 1, January 2021

Available online at: https://journal.umy.ac.id/index.php/FTL/issue/view/720

e-ISSN: 2580-2070, p-ISSN: 2527-7650

tool to understand passages. Authors also found that it influences reasoning in reading comprehension. It was carried out with one hundred and fourteen fifth graders from five different public elementary schools of an urban area in the north of Israel (Shahar-Yames \& Prior, 2018).

Participants of a private language institute were obtaining low scores in the reading section of tests. This study focused on word recognition through parts of speech, and the use of skimming and scanning as a means to improve students' reading comprehension. Therefore, the following research questions were addressed: (1) To what extent will students identify parts of speech in context? (2) To what extent will students improve their reading comprehension as result of word recognition and the use of skimming and scanning? (3) What are students' perspective of this process to improve reading comprehension?

\section{Literature Review}

\section{Reading Skills}

Reading is considered a step-by-step procedure which fosters development of higher-order thinking skills. The basic elements of reading are to decode the message, comprehend the message, analyze it, and integrate the whole idea of a text. (Karademir \& Ulucinar, 2017). Some researchers advocated that children and teens have an important performance in reading accomplishment when they have a vast prior wisdom and words range domain (Kieffer \& Lesaux, 2012; Shahar-Yames \& Prior, 2018; Snow, 2002).

Reading instruction possesses five elements which are: phonemic awareness, phonics, word recognition, vocabulary, and comprehension. They all allow the reader to obtain the basic reading skills to be an acceptable reader (Gunobgunob-Mirasol, 2019). Abdullah (2018) added that reading can be improved by the use of some activities and techniques such as skimming and scanning. Jose and Raja (2011) pointed out that scanning is stopping reading until the information is found to answer a specific question while skimming is the process of grasping the main idea of the whole text.

Granda and Ramírez-Avila (2020) described reading comprehension as the act of processing and understanding a text. It allows readers to make connections between their prior knowledge and the same or new content to understand it. Activities that raise reading comprehension are repeated reading, timed-reading, and rate-building reading (Abdullah, 2018). 
Journal of Foreign Language Teaching and Learning

Volume 6, No. 1, January 2021

Available online at: https://journal.umy.ac.id/index.php/FTL/issue/view/720

e-ISSN: 2580-2070, p-ISSN: 2527-7650

\section{Vocabulary}

According to Mofareh (2015), vocabulary is defined as the units of speech or writing needed to convey a message in written and spoken forms. Harmon and Wood (2018) stated that the aim of vocabulary instruction is to improve and advocate for deep reading understanding. Similarly, in another finding it was evidenced that students may achieve the basic knowledge of lexical size to obtain an in-depth reading comprehension (Rosado \& Caro, 2018). Maximo argued that researchers believed that devoting a lot of time to learn vocabulary is essential to master a language (as cited in Mofareh, 2015). In line with this, Laufer and Ravenhorst-Kalovski (2010) confirmed that vocabulary is a good predictor for reading.

For greater improvement on the teaching of vocabulary, Mofareh (2015) mentioned some strategies and techniques teachers can apply such as focusing on form and on meaning, recalling short- and long-term memory, employing real objects, using cooperative learning strategies, incorporating a wide variety of learner preferences, applying total physical response, introducing lexical sets within a defined cultural context, drilling, and spelling. Nevertheless, McQuillan (2019) concluded that free reading was 1.70 more efficient to learn vocabulary rather than teaching vocabulary in short and long periods.

McCarten (2007) devised three main categories to organize lexical sets to help learners memorize a wide range of new words: real-world groups, language-based groups, and personalized groups. The greater the range of lexical sets that a language learner knows, the better their communicative abilities can be even when using inaccurate grammar structures due to their expanded range of comprehensible expression. However, without an adequate vocabulary repertoire, the ability to convey any concept is drastically hindered (Wilkins, 1972).

There is an impact of vocabulary in the development of reading. Learners get better scores when taking test because of the guessing of the meaning of some words and by relating meaning with the root of a word itself. In addition to raising communicative competence by developing vocabulary knowledge, learners also gain the peripheral advantage of performing better in written evaluations. A study conducted by Senoo and Yonemoto (2014) stated that new words are only acquired when the learners have needs: the need to know what the word means, the need to find the significance of that word by themselves, and the need to compare the different meaning of words. Motivation is also important for reading so a good attitude to learn and acquiring new 
Journal of Foreign Language Teaching and Learning

Volume 6, No. 1, January 2021

Available online at: https://journal.umy.ac.id/index.php/FTL/issue/view/720

e-ISSN: 2580-2070, p-ISSN: 2527-7650

words is also vital. Thus, readers may understand the text but if they are not motivated they may not be a good reader (Gunobgunob-Mirasol, 2019).

\section{Parts of Speech}

One way to improve the lexical width and sets of students is by identifying the parts of speech. In this study, participants will read and classify new words into their parts of speech. This classification will meet McCarten's (2007) organization of words to help students memorize them. Additionally, Skehan as cited in Ellis (2005) advocated that students should possess a vast range knowledge of expressions and parts of speech to compile accuracy. Porosoff (2018) contributed with the definitions of some parts of speech: Adjectives describe traits; verbs show behaviour; adverbs show how the actions are performed; nouns show who or which the performers of the actions are; conjunctions are used to combine or mix ideas in statements; and, pronouns replace the antecedents.

\section{Methodology}

This was an action-research with analysis of qualitative and quantitative data. Ravid (2015) defined Action Research (AR) as a tool used by practitioner researchers in their context to deal with problematic situations. Additional, Burns (2008) made a revision of the purposes of AR from different authors' perspectives. She mentioned: to describe and understand the processes carried in classroom settings that lead to change, and to explain classroom procedures supported by academic findings, among others. For Burns (2008), action research brings improvement and change in a variety of contexts. In this case, the context was the classroom.

$\mathrm{AR}$ is a cyclical process. It starts by defining a problem, researching for possible solutions, applying an intervention, assessing the results, and continuing the process (Ravid, 2015). In this study, the cycle was implemented once. It is important to highlight that students applied the classification of words and skills seven times during the study. During that time, the teacher was observing, monitoring, and providing feedback as it is seen in Table. 1. 
Journal of Foreign Language Teaching and Learning

Volume 6, No. 1, January 2021

Available online at: https://journal.umy.ac.id/index.php/FTL/issue/view/720

e-ISSN: 2580-2070, p-ISSN: 2527-7650

Table. 1. Action Research Phases

\begin{tabular}{|c|c|c|c|c|}
\hline Phase & Problem & Possible Solution & Application & Assessment \\
\hline \multirow[t]{6}{*}{ Action } & Students in a & Knowing & See the classroom & They are included \\
\hline & language school & meaning & procedures & in the \\
\hline & reported low & function of the & detailed below for & section. \\
\hline & grade in reading & words (Classifying & the description of & \\
\hline & tests. & parts of speech) and & this phase. & \\
\hline & & reading skills. & & \\
\hline
\end{tabular}

\section{Participants}

Students $(\mathrm{N}=15)$ from a private English language institute participated in the study. There were eight females and seven males. Participants' ages ranged from fourteen to sixteen years old. Their English level was intermediate to upper-intermediate (equivalent to Level B1 of the Common European Framework of Reference for Languages, CEFR). Their proficiency was determined based on the program they were immersed in- Teens 6 .

The researcher, who also served as the class teacher, invited students to participate in the study. They were informed that their participation was voluntary. They were also assured that their test scores and survey responses would be kept confidential and would not affect their course grades.

The study integrated the use of Google sheets in drive. Students had to insert new words and classify them into the different parts of speech. Regarding the access to technology, fourteen out of fifteen students answered they had access to the internet. In the pre survey related to the use of the application, all students had an e-mail account, but only three of them knew how to use it.

\section{Classroom Procedures}

In order to help students improve their reading comprehension, this innovation aimed to extend students' word recognition through classifying new vocabulary into parts of speech and applying reading skills (skimming and scanning). The classification of words was done in groups. Each group shared a sheet document in drive. Students had a Gmail account, they knew how to share documents and how to navigate within the Google sheets. There were three students who 
Journal of Foreign Language Teaching and Learning

Volume 6, No. 1, January 2021

Available online at: https://iournal.umy.ac.id/index.php/FTL/issue/view/720

e-ISSN: 2580-2070, p-ISSN: 2527-7650

had shared a document before. Thus, a training on how to use Google sheets was planned and delivered for those that had not used this application before.

Parts of speech were introduced and practiced. The teacher selected passages according to students' level and interests. New words for students were selected from passages and introduced at the beginning of the lesson with a variety of techniques: pictures, videos, definitions, and synonyms. This new vocabulary was classified in the shared sheet according to the vocabulary function in context (parts of speech). The teacher's role was to guide and scaffold the activities during the process as well as to provide feedback.

To improve reading comprehension, the teacher introduced a form which included skimming and scanning activities. The teacher and students completed it together at the beginning. Later on, students completed it individually. Once the form was filled in, students compared with a classmate. The forms were corrected in class. In every other class, students conducted individual practices regarding skimming and scanning.

\section{Instruments}

The following instruments were used in the study: (1) a demographics survey; (2) a pre-and post-tests about reading; (3) learning logs; (4) a pre-post survey about vocabulary; and, (5) skimming and scanning forms, and (5) a semi-structure interviewed. The surveys, learning logs and interview were presented in the target language and in students' mother tongue, to ensure that the questions and instructions were easy to understand and answer.

Demographic survey: The researcher took this survey to gather information relevant to participants' background such as age, gender, profession, English language proficiency and English language experiences. This information was used to describe the participants.

Pre-test and Post-test: The pre-test was administered to determine if students recognized and classified words correctly into their parts of speech. It contained twenty items. The post-test was used to assess the participants' vocabulary improvement and effectiveness of the study, respectively. The text of the posttest was longer and had fifteen multiple choice questions. Both tests were graded over 10 points. Three EFL specialists validated the content of these tests for this study. The passages were taken from the placement test of the book students were using.

Learning logs: Learners wrote their reflections about what they learned at the end of the class. Similarly, the information obtained was a referent to compare and analyze the results. In these logs, there were open-ended questions which referred to vocabulary and reading 
Journal of Foreign Language Teaching and Learning

Volume 6, No. 1, January 2021

Available online at: https://journal.umy.ac.id/index.php/FTL/issue/view/720

e-ISSN: 2580-2070, p-ISSN: 2527-7650

comprehension reflections. This qualitative data was transformed to quantitative information. Students completed six learning logs.

Pre-post surveys about vocabulary: They were used to have a general idea of the perspective and knowledge students had about vocabulary and reading comprehension. They were taken from Granda and Ramírez-Avila's (2020) study. The authors reported a Cronbach's Alpha of 0.903 for the pre-survey and 0.902 for the post-survey.

Skimming and scanning form: These forms were introduced by the teacher-researcher. The first one was introduced and done by the teacher as an example. Following forms were completed by students. The teacher provided feedback about them. For the analysis, three of them were chosen. These forms were graded over 10 points.

Interview: It was conducted at the end of the study. Students answered to eight questions. They were open questions. They asked about vocabulary in terms of difficulty, confidence using the new words, perspectives about improvement, importance of vocabulary learning, and the incidence of vocabulary knowledge in understanding texts. Four participants were randomly chosen to be interviewed. It was carried out in Spanish to obtain reliable information.

\section{Data Analysis}

The study was conducted over a period of six weeks during the September through January semester. Quantitative data was analyzed with the use of SPSS statistical software. Means, standard deviations, and $p$ value were run to examine differences between pre- and post-test scores. Qualitative data were analyzed by identifying patterns in student responses to open-ended questions in the learning logs and the interview. After reading students had to complete skimming and scanning worksheets, they were graded; for the purpose of the analysis, three forms were considered: the first, the one in the middle, and the last. Results are shown in a figure to visually compare the means. Information from the instruments was triangulated to validate results. To determine the impact of this study the Cohen's $d$ was reported.

\section{Results}

Research Question 1: To what extent will students identify parts of speech in context? Results are presented in table 1 . The mean of the pre-test was $5.53(\mathrm{SD}=2.41)$. The mean of the post-test was $8.35(\mathrm{SD}=2.77)$. Cohen's $d$ was calculated and it resulted in 1.09 , which indicates a 
Journal of Foreign Language Teaching and Learning

Volume 6, No. 1, January 2021

Available online at: https://journal.umy.ac.id/index.php/FTL/issue/view/720

e-ISSN: 2580-2070, p-ISSN: 2527-7650

great effect. The $p$ value was 0.005 which means the results did not happen coincidentally. It is shown in Table. 2.

Table. 2. Pre-Post test results

\begin{tabular}{llllll} 
& & & $\begin{array}{l}\text { Standard } \\
\text { Deviation }\end{array}$ & $\begin{array}{l}\text { Standard Error } \\
\text { Mean }\end{array}$ & Cohen's d \\
\hline Pre-test & 15 & 5.53 & 2.40 & 0.62 & 1.09 \\
\hline Post-test & 15 & 8.35 & 2.77 & 0.71 &
\end{tabular}

In the pre and post survey from items 8 to 12 that are related to the improvement of the identification of parts of speech, the data was compared. Results show that there was an improvement from the results of the pre-survey with a mean of 4.04 to a mean of 4.59 obtained from the post-survey. Figure 1 also shows students' perspectives of improvement related to different categories of words functions at the end of the innovation. It is evident that in the post test there was a positive change of improvement.

Figure 1. Parts of Speech Improvement taken from the Pre and Post Surveys from Vocabulary

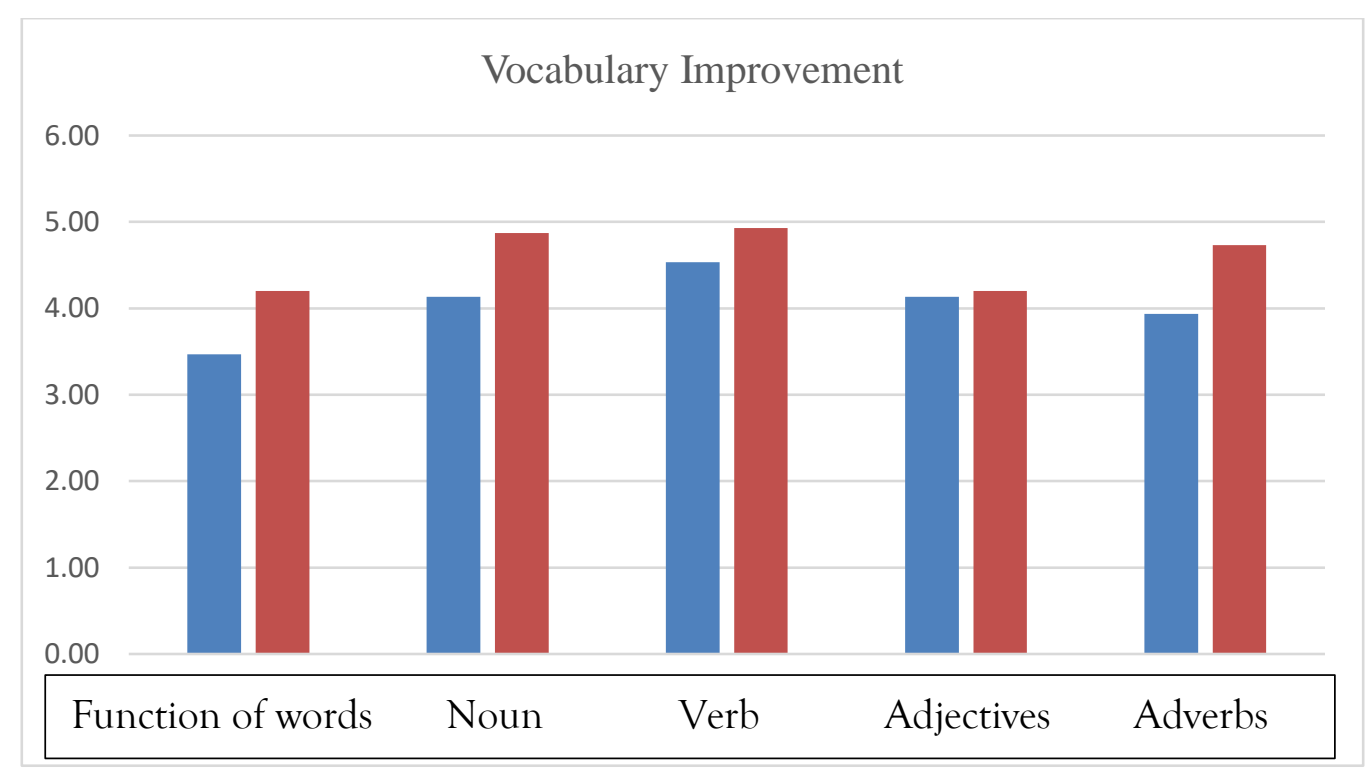

Note: Blue color is the results of the pre-survey and red color displays the results of the posttest.

From the data collected of the learning logs, there were two open-ended questions in four learning logs which were applied. This qualitative information was transformed to quantitative to make a better analysis. In Table. 3 , there is a summary of students' answers. Most of the students referred to the acquisition of the new words and their functions as nouns, verbs, 
Journal of Foreign Language Teaching and Learning

Volume 6, No. 1, January 2021

Available online at: https://journal.umy.ac.id/index.php/FTL/issue/view/720

e-ISSN: 2580-2070, p-ISSN: 2527-7650

adjectives, adverbs, conjunctions, prepositions, and interjections. Thus, students considered they learned to classify words into parts of speech.

Table. 3. Learning Logs and Vocabulary Development

\begin{tabular}{lllll} 
Opinions and Comments & $\log 1$ & $\log 2$ & $\log 3$ & $\log 4$ \\
\hline Parts of Speech & 14 & 7 & 3 & 4 \\
\hline New Words & $\mathrm{X}$ & $\mathrm{X}$ & 6 & 5 \\
\hline Other Answers related to reading comprehension & 1 & 8 & 6 & 6 \\
\hline Total & 15 & 15 & 15 & 15
\end{tabular}

Furthermore, within the interviews, participants mentioned that their level of vocabulary knowledge had increased. Here some extracts from what they said in the interviews: Participant 1: "I think my vocabulary has increased." Participant 4: "My confidence has increased."

Research Question 2: To what extent will students improve their reading comprehension as result of word recognition and the use of skimming and scanning? The analysis of the scaffolding forms showed that learners steadily increased their reading understanding of most of the activities during the research. Those activities were graded over 10 points. Figure 2 displays the scores of the skimming and the scanning worksheets applied. It is important to highlight that the difficulty of the readings increased during the process from an intermediate passage to a high intermediate one.

Figure 2. Skimming and Scanning Worksheets

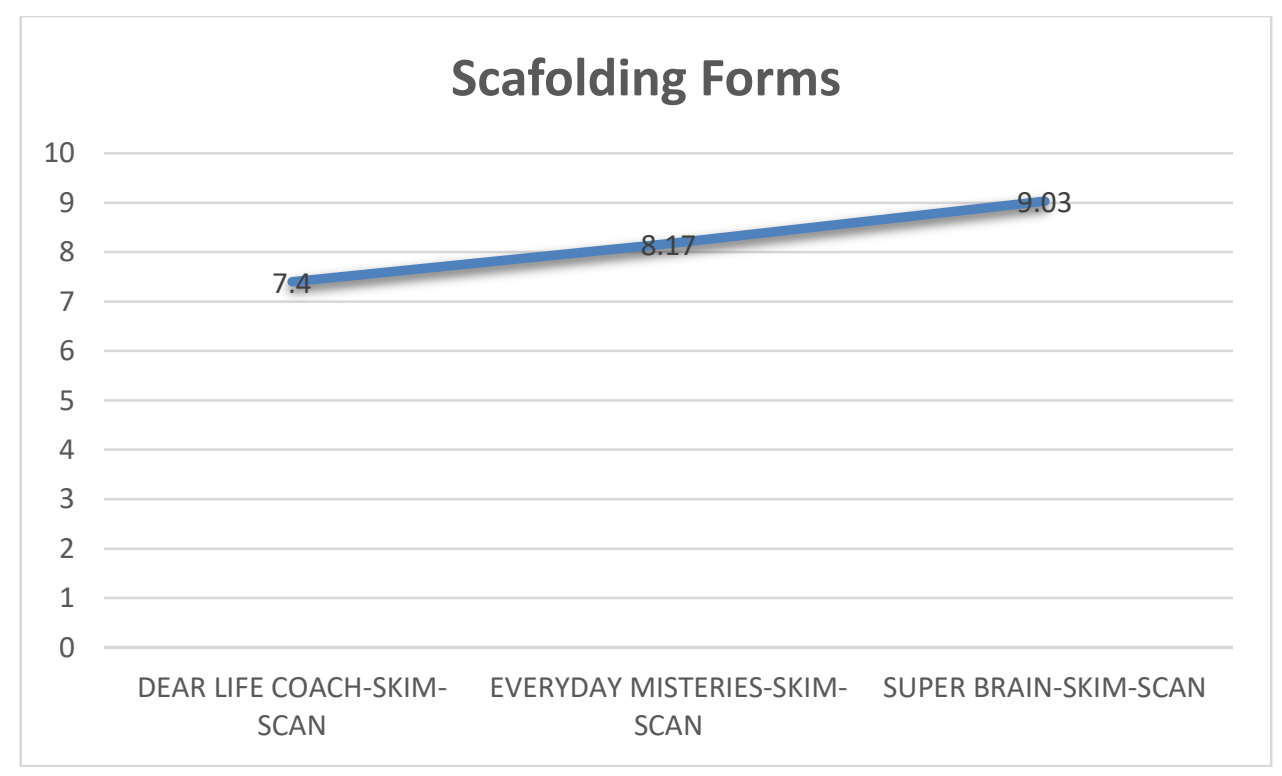


Journal of Foreign Language Teaching and Learning

Volume 6, No. 1, January 2021

Available online at: https://journal.umy.ac.id/index.php/FTL/issue/view/720

e-ISSN: 2580-2070, p-ISSN: 2527-7650

Figure 3 compares the pre and post survey between the items 6 and 7 regarding the knowledge of the skimming and scanning from students' perspectives. The improvement is notorious with a Mean= 4.93 for both strategies.

Figure 3. Skim and Scan Strategies Improvement for Reading Comprehension

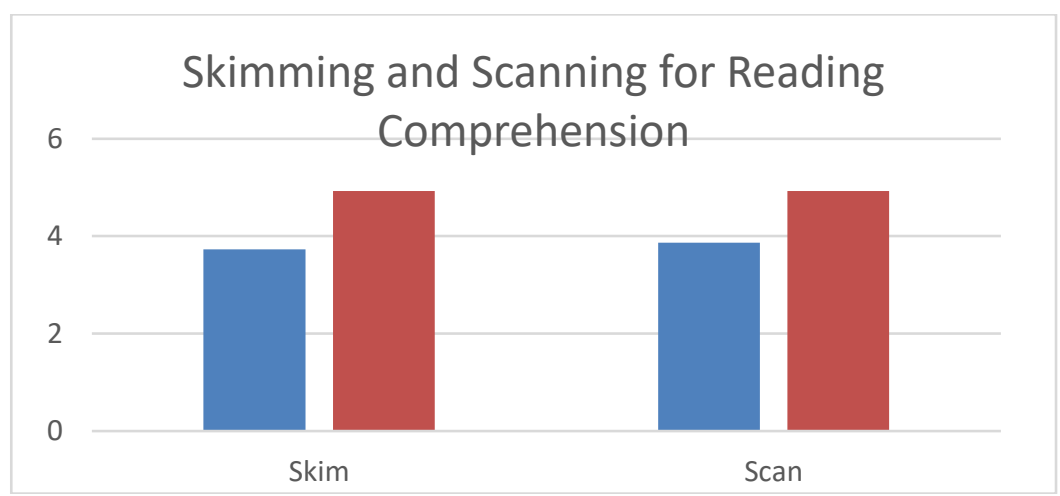

Note: Blue color is the results of the pre-survey and red color displays the results of the posttest.

The pre and post surveys about reading comprehension were compared in order to determine their improvement. Figure 4 presents the variation in the participants' perspectives related to improvement.

Figure 4. Pre-Post Survey Reading Comprehension

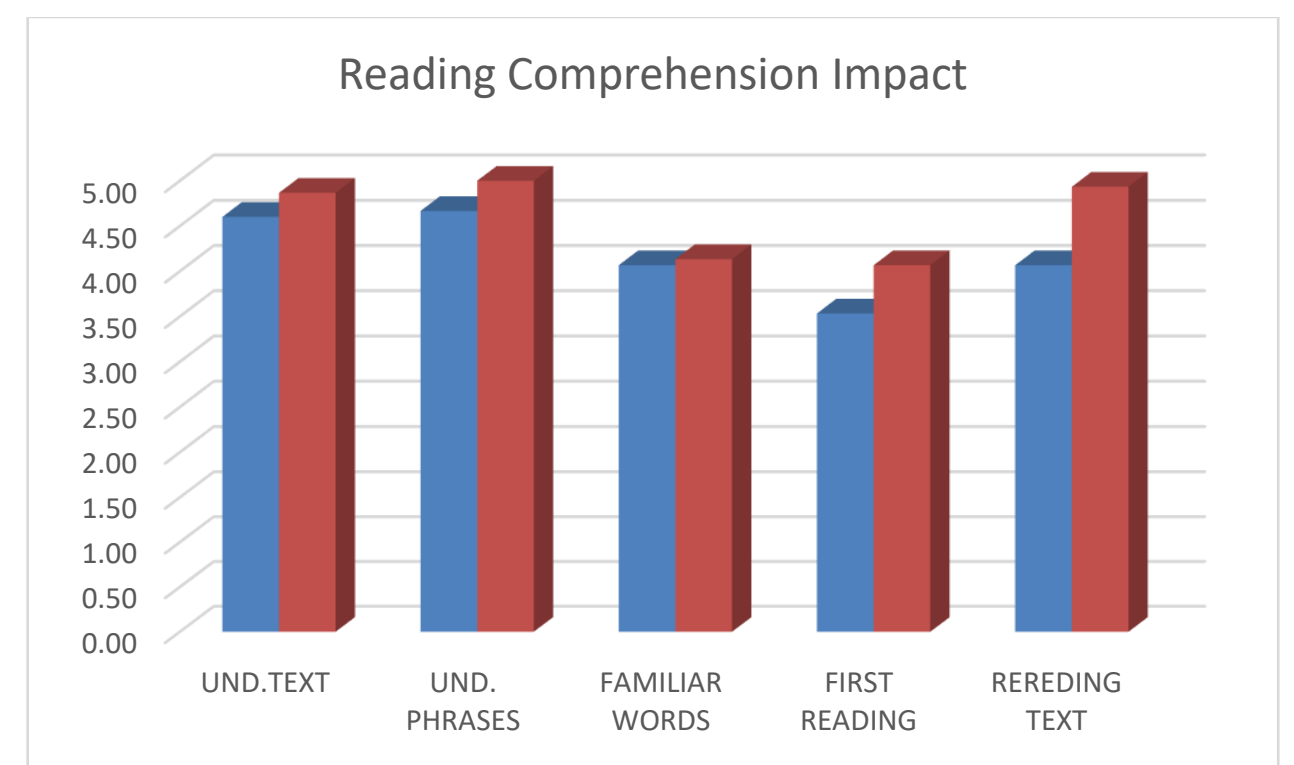

Note: Blue color is the results of the pre-survey and red color displays the results of the posttest.

The learning logs also evidenced that after every class, most students learned the strategies: skimming and scanning. Eleven students referred to the scanning and eight to the skimming strategy in the learning logs. 
Journal of Foreign Language Teaching and Learning

Volume 6, No. 1, January 2021

Available online at: https://journal.umy.ac.id/index.php/FTL/issue/view/720

e-ISSN: 2580-2070, p-ISSN: 2527-7650

Research Question 3: What are students' perspective of this process to improve reading comprehension? An analysis of the learning logs showed they had a good attitude with the use of the innovation to learn parts of speech facilitated with the e-tool. A revision of the Google Drive sheet also reflected they all worked and introduced words in the different categories. Table. 4 shows that most students met their expectations with this innovation.

Table. 4. Students' perspectives

\begin{tabular}{|c|c|c|c|c|c|}
\hline & & Frequency & Percent & Valid Percent & Cumulative Percent \\
\hline \multirow[t]{3}{*}{ Valid } & Yes & 13 & 86.7 & 86.7 & 86.7 \\
\hline & No & 2 & 13.3 & 13.3 & 100 \\
\hline & Total & 15 & 100 & 100 & \\
\hline
\end{tabular}

Additionally, the interview supported the data about the improvement they had achieved and the difficulties they had when they classified the words into their parts of speech at the beginning. Here is an extract of some of the words taken from the dialogue of the interview videos: Participant 1: "I think the most difficult part in the reading was parts of speech." Participant 2: "for me the most difficult thing is to identify the parts of speech"; Participant 3: "No, it was so easy because we have to put the words and do some easy things"; Participant 4: "The most difficult part for me was the meaning of vocabulary words and parts of speech."

However, two out of the four students interviewed, mentioned that in the end, they had a good experience about knowing how to classify the parts of speech into the Excel-Spreadsheet into the Google Drive: Participant 1: "the tool is humm... that is... it was easy...that I know... the words that I know I put in the sheet. Besides this, the sheet was to improve my vocabulary because I recognize new parts in the sentence or texts."; Participant 2: "it was easy because I can put the words in order and my friends helped me in some things for example when I put the answers according to the readings... my Friends help me to know how the readings and what are the things I have to do."

\section{Discussion}

The current study examined the impact that vocabulary, skimming and scanning skills had on the process of improving reading comprehension. Findings of this study reflect an improvement of $d=1.09$. The impact of the intervention is large. The skimming and scanning forms that students complete during the study also showed a steady improvement. It is important 
Journal of Foreign Language Teaching and Learning

Volume 6, No. 1, January 2021

Available online at: https://journal.umy.ac.id/index.php/FTL/issue/view/720

e-ISSN: 2580-2070, p-ISSN: 2527-7650

to recall that the level of difficulty of the passages also increased during the intervention. Abdullah (2018) recommended that skimming and scanning can improve reading comprehension.

This study included not only the reading strategies (skimming and scanning) but also word recognition through the classification of words into their parts of speech. This coincides with Karademir and Ulucinar's (2017) step-by-step procedure that starts by decoding the message to later comprehend it. Additionally, Maximo (cited in Mofareh, 2015), Harmon and Wood (2018), and Rosado and Caro (2018) stated in their study, the fundamental role of vocabulary to booster reading comprehension, the bigger range of vocabulary they possess the better for deeper text's comprehension. These findings match some author's conclusions that vocabulary size contributes to reading comprehension (Gunobgunob-Mirasol, 2019; Kieffer \& Lesaux, 2012; Laufer \& Ravenhorst-Kalovski, 2010; Shahar-Yames \& Prior, 2018; Snow, 2002).

In this research, students learned to identify the different parts of speech, and they classified them after each reading which displayed a steady progress. In the post survey related to vocabulary improvement students positively changed their perspective about vocabulary recognition. While the pre survey, the mean was equal to 4.04 , on the post survey, there was a mean of 4.59. Students knowing the function and meaning of the words and their better comprehension of the texts might have changed their perspectives.

Furthermore, Gunobgunob-Mirasol (2019) stated that word recognition is one of the elements that allow the reader to be considered an acceptable reader. Students' performance on the scaffolding forms was acceptable as their improvement was evidenced through the grading done after every lesson.

While building word recognition skills, reading comprehension was impacted. The scaffolding forms scores, for example, captured that there was a significant improvement in their ability to read after the process, which is aligned to what Capotosto et al., (2017) mentioned that learners have better performance when they have a vast range of vocabulary knowledge.

In the learning logs, students referred to two main strategies in this investigation which were skimming and scanning. Abdullah (2018) mentioned that apart from other language elements the skimming and scanning skills can booster reading comprehension. Due to the practices done during classes, most students mentioned in the post survey that they could use 
Journal of Foreign Language Teaching and Learning

Volume 6, No. 1, January 2021

Available online at: https://iournal.umy.ac.id/index.php/FTL/issue/view/720

e-ISSN: 2580-2070, p-ISSN: 2527-7650

the skimming and scanning techniques. Identifying the main idea and specific information may have helped students to also improve the results in the posttests.

Tang et al. (2016), in their study, mentioned that it is vital for learners to develop an affirmative learning attitude, set clear objectives, and increase a course for language awareness and use. Motivation is also important for reading so a good attitude to learn and get new words is also vital. Thus, a reader may understand the text but if they are not motivated s/he may not be a good reader (Gunobgunob-Mirasol, 2019). Results of students' perspectives showed that participants of this study felt satisfied with the skills and resources applied in this innovation. So, they recommended to continue with the same practices to improve reading. This implies that when students notice they are learning and understanding through the proposed activities they become engage and participate in the lessons.

\section{Conclusion}

In this study, learners differentiated parts of speech in order to recall and expand their vocabulary, and were trained to use skimming and scanning. Post results of the study showed that learners' word knowledge and reading strategies were to a great extent effective to improve reading comprehension.

During the classes, students defined words well, created almost accurate sentences, and classified the words in the shared document. The shared document let students see the new words of their classmates which also expanded vocabulary knowledge. In an analysis of the classification of words in the shared document, ninety percent of the words that were introduced, were classified appropriately. This practice helped students to retain the meaning of the words. Participants claimed to have learned more about how to classify parts of speech in context. The study also sheds light on the great potential of making use of existing technology like a shared document in Drive for learning.

\section{Limitations}

It has to be considered that there were not studies conducted at school, high school or institutional levels in order to have a better support of cases previously conducted. Time was another influential factor on getting a better consistency of the data obtained. Sometimes, the different activities planned during the process of the intervention was sort of rushed because students were in a hurry most of the time due to the limited sixty minutes they had in class. The influence of the teacher as the researcher may also affect the veracity of the data, as some of them 
Journal of Foreign Language Teaching and Learning

Volume 6, No. 1, January 2021

Available online at: https://journal.umy.ac.id/index.php/FTL/issue/view/720

e-ISSN: 2580-2070, p-ISSN: 2527-7650

might feel the whole process was graded even when they were told that none of the activities in this study would be considered as part of their grades.

\section{Recommendations}

The classification of words into their parts of speech can be applied to improve the other skills of the language. More time should be given to students to work on all the activities. Students have to attend classes during the whole process, so if they missed one class they had to catch-up in an extra class as an alternative for the analysis of the results later. Furthermore, the planning of the instructional design has to have a variety of activities so that all the participants are addressed with one of their learning styles. Finally, this research can be applied to a different group of students who do not have the researcher as their teacher, or an assistant might help apply the research.

\section{References}

Abdullah, M. (2018). Reading speed and comprehension enhancement in hybrid learning delivery mode. Advances in Language and Literary Studies, 9(3), 25-33. http://dx.doi.org/10.7575/aiac.alls.v.9n.3p.25

Burns, A. (2008). Action research in second language teacher education. In A. Burns \& J. Richards (Eds.), The Cambridge Guide to Research In Language Teaching and Learning. (pp. 289. 297). Cambridge: Cambridge University Press.

Capotosto, L., Kim, J. S., Burkhauser, M., Oh Park, S., Mulimbi, B., Donaldson, M., \& Kingston, H. C. (2017). Family support of third-grade reading skills, motivation, and habits. AERA Open, 3(3), 1-16. https://doi.org/10.1177/2332858417714457

Ellis, R. (2005). Principles of instructed language learning. Asian EFL Journal, 7(3) 209-224. Retrieved from https://www.asian-efl-journal.com/9016/quarterly-journals/principles-ofinstructed-language-learning/\#squelch-taas-tab-content-0-3

Education First. (2020). EF English Proficiency Index. Retrieved from https://www.ef.com/epi/

Granda, G. K. A., \& Ramírez-Avila, M. R. (2020). Classifying vocabulary in Google Sheets to improve word recognition and reading comprehension in EFL learners: An action research study. AtoZ: novas práticas em informação e conhecimento, 9(2), 24 - 31. https://doi.org/10.5380/atoz.v9i2.73526

Gunobgunob-Mirasol, R. (2019). Vocabulary size, reading motivation, reading attitudes and reading comprehension performance among Filipino college learners of English. International Journal of Evaluation and Research in Education (IJERE), 8(1), 64. https://doi.org/10.11591/ijere.v8i1.15335 
Harmon, J., \& Wood, K. (2018). The vocabulary-comprehension relationship across the disciplines: Implications for Instruction. Education Sciences, 8(3), 101. https://doi.org/10.3390/educsci8030101

Instituto Nacional de Estadísticas y Censos. (2012). Hábitos de Lectura en Ecuador [Reading Habits in Ecuador]. Retrieved from http://www.celibro.org.ec/web/img/cms/ESTUDIO\%20HABITOS\%20DE\%20LECTU $\underline{\text { RA\%20INEC.pdf }}$

Jose, R., \& Raja, B. W. D. (2011). Teachers role in fostering readings: effective and successful reading. I-Manager'S Journal On English Language Teaching, 1(4), 1-10. https://doi.org/10.26634/jelt.1.4.1599

Karademir, E., \& Ulucinar, U. (2017). Examining the relationship between middle school students' critical reading skills, science literacy skills and attitudes: A structural equation modeling. Journal of Education in Science, Environment and Health (JESEH), 3(1), 29-39. Retrieved from https://files.eric.ed.gov/fulltext/EJ1125758.pdf

Kieffer, M., \& Lesaux, N. (2012). Direct and indirect roles of morphological awareness in the English reading comprehension of native English, Spanish, Filipino, and Vietnamese. Language Learning, 62(4), 1170-1204. https://doi.org/10.1111/j.1467-9922.2012.00722.x

Laufer, B., \& Ravenhorst-Kalovski, G. (2010). Lexical threshold revisited: Lexical text coverage, learners' vocabulary size and reading comprehension. Reading in a Foreign Language, 22(1), 15-30. Retrieved from http://nflrc.hawaii.edu/rfl

McCarten, J. (2007). Teaching Vocabulary: lessons from the corpus, lessons for the classroom. Cambridge: Cambridge University Press.

McQuillan, J. (2019). The Inefficiency of Vocabulary Instruction. International Electronic Journal of Elementary Education, 11(4), 309-318. https://doi.org/10.26822/iejee.2019450789

Ministerio de Educación. (2012). Estándares de Calidad Educativa [Educational Quality Standards]. Retrieved from http://educacion.gob.ec/wpcontent/uploads/downloads/2012/09/estandares_2012_ingles_opt.pdf

Mofareh, A. (2015). The importance of vocabulary in language learning and how to be taught. International Journal of Teaching and Education, 3(3), 21-34. https://doi.org/10.20472/TE.2015.3.3.002

Organization for Economic Cooperation and Development [OECD]. (2016). PISA 2015 Results (Volume I): Excellence and Equity in Education. Paris: OECD Publishing. Retrieved from https://www.oecd-ilibrary.org/docserver/9789264266490en.pdf? expires $=1564898092 \&$ id $=i d \&$ accname $=$ guest $\&$ checksum $=5295096$ E7538242CE 8 FEEA06B4FE3ED6 
Porosoff, L. (2018). How our word choices can empower our students. Phi Delta Kappan, 100(3), 51-54. https://doi.org/10.1177/0031721718808265

Ravid, R. (2015). Practical Statistics for Educators. Maryland: Rowman \& Littlefield.

Rosado, N., \& Caro, K. (2018). The relationship between lexis and reading comprehension: A review. English Language Teaching, 11(11), 136. https://doi.org/10.5539/elt.v11n11p136

Senoo, Y., \& Yonemoto, K. (2014). Vocabulary learning through extensive reading: A case study. The Canadian Journal of Applied Linguistics, [online] 17(2), pp.1-22. Retrieved from: https://files.eric.ed.gov/fulltext/EJ1064814.pdf

Shahar-Yames, D., \& Prior, A. (2018). The challenge and the opportunity of lexical inferencing in language minority students. Reading and Writing, 31(5), 1109-1132. https://doi.org/10.1007/s11145-018-9830-0

Short, D., Becker, H., Cloud, N., Hellman, A., Levine, L., \& Cummins, J. (2018). The 6 principles for exemplary teaching of English learners. Danvers, MA: Anita Draper.

Snow, C. (2002). Reading for understanding. Santa Monica: RAND Education.

Tang, E., Chung, E., Li, E., \& Yeung, S. (2016). Online independent vocabulary learning experience of Hong Kong University Students. IAFOR Journal of Education, [online], 4(1). Retrieved from: https://eric.ed.gov/?q=Online+Independent + Vocabulary + Learning + Experience + of + Hong + Kong+University+Students ++ Eunice $+\&$ id $=$ EJ1100577

Wilkins, D. (1972). Linguistics and Language Teaching. London: Edward Arnold National Middle School Association. 